\title{
Genetic diversity of the Acropora-associated hydrozoans: new insight from the Red Sea
}

Davide Maggioni, $1,{ }^{*}, 2$

Phone +390264483433

Email davide.maggioni@unimib.it

Simone Montano, 1,2

Roberto Arrigoni, 3

Paolo Galli, 1,2

Stefania Puce, 4

Daniela Pica, 4

Michael L. Berumen, ${ }^{3}$

1 Dipartimento di Biotecnologie e Bioscienze, Università degli Studi di Milano-Bicocca, Piazza della Scienza 2, 20126 Milan, Italy

2 MaRHE Center, Università degli Studi di Milano-Bicocca, Magoodhoo Island, Faafu Atoll, Republic of Maldives

3 Red Sea Research Center, Division of Biological and Environmental Sciences and Engineering, King Abdullah University of Science and Technology, Thuwal, 23955-6900 Saudi Arabia

4 Dipartimento di Scienze della Vita e dell'Ambiente, Università Politecnica delle Marche, via Brecce Bianche, 60131 Ancona, Italy

\begin{abstract}
To date, four nominal species and several other unidentified species of Zanclea hydrozoans are known to live symbiotically with scleractinians, and recent surveys reported this association also in the Red Sea. Previous molecular studies showed that each coral genus involved in this association hosts only one species or molecular clade of Zanclea, with the only exception being the genus Acropora, which hosts at least two Zanclea species. Moreover, some of the detected genetic lineages were morphologically undistinguishable in the polyp stage, suggesting the presence of cryptic species. In this study, we investigated the morphology and genetic diversity of Acropora-associated Zanclea specimens collected in previous studies in Egypt and Israel, as well as new samples collected in Saudi Arabia. Based on the current data, all the analysed samples were morphologically identical to Zanclea gallii, a species associated with Acropora corals from the Maldives. However, molecular analyses separated the samples collected in the Red Sea from all other coral-associated hydroids. Therefore, phylogenetic reconstructions, haplotype networks, genetic distance analyses and distribution data allowed us to identify a previously unknown cryptic species of Acropora-associated hydroid, here named Zanclea gallii IIa, following a recently proposed molecular nomenclature.
\end{abstract}




\section{Keywords}

Symbiosis

Zanclea

Integrative taxonomy

Cryptic species

Biodiversity

Coral reefs

Molecular nomenclature

Communicated by Moritz Sonnewald

\section{Electronic supplementary material}

The online version of this article (doi: 10.1007/s12526-017-0632-4 ) contains supplementary material, which is available to authorized users.

\section{Introduction}

The Red Sea is a hotspot for endemism, hosting high percentages of endemic taxa (Guinot 1967; Campbell 1987; Randall 1994; Hughes et al. 2002; Shenkar 2012; DiBattista et al. 2016a, b) and outstanding biodiversity, with the list of marine organisms being continuously revised due to descriptions of new nominal and cryptic species (e.g. Tornabene et al. 2013; Terraneo et al. 2014; Alamaru et al. 2016; Arrigoni et al. 2016). Traditionally, coral reef research has predominantly focused on the most conspicuous organisms, such as fish and corals, and non-coral invertebrates have often been overlooked (Stella et al. 2011). Since the latter group is known to provide the greatest biodiversity to coral reef environments (Bouchet et al. 2002; Stella et al. 2011; Appeltans et al. 2012) and to harbour a high cryptic diversity (Knowlton 2000), the magnitude of the Red Sea fauna is likely to be underestimated in terms of species richness (Berumen et al. 2013). Among invertebrates, hydrozoans have been poorly investigated in the Red Sea and a total of 160 valid species of non-siphonophoran hydrozoans have been recorded so far (Gravili et al. 2013; Seveso et al. 2015; Pica et al. in press). Only one of these species is known to occur solely in the Red Sea, i.e. Zanclea eilatensis Pica, Bastari \& Puce living in association with bryozoans, whereas all other species are reported also from other localities of the Indo-Pacific. Recently, Montano et al. (2014) and Pica et al. (in press) reported the presence of coral-associated hydrozoans belonging to the genus Zanclea Gegenbaur, 1856 in Dahab and Eilat, respectively, extending the geographic distribution and the host range of this symbiosis, and confirming the hypothesis that this association is more widespread than previously known (Millard and Bouillon 1974; Boero et al. 2000; Pantos and Bythell 2010; Hirose and Hirose 2012; Fontana et al. 2012; Montano et al. 2013, 2015a, b, c, 2016a). Molecular phylogenetic analyses have revealed that Zanclea hydroids are associated with their coral hosts with a variable degree of specificity, resulting in either generalist interactions or genus-specific associations (Fontana et al. 2012; Montano et al. 2015b). Moreover, despite very low or even undetectable morphological variation, Zanclea hydrozoans living in symbiosis with corals show a remarkable genetic diversity and some of the recovered lineages could represent independent species. This genetic diversity might be explained by host-specificity, since each molecular clade is associated with either a specific host genus or a group of genera (Montano et al. 2015b). Schuchert (2014) also found a similar strong genetic structure for the hydrozoan Plumularia setacea, likely due to geography, and highlighted that choosing different species concepts when discussing the species status of populations can result in opposite conclusions. For instance, different monophyletic clades identified with multiple markers and belonging to the same morphospecies constitute a 
species complex following the genealogical species concept (Baum and Shaw 1995) or an extensive population subdivision according to morphology-based species definitions.

In the Maldives, 13 genera of corals were examined, and each was found to host its own unique genetic clade of Zanclea (Montano et al. 2015b). Contrarily, the species Zanclea margaritae Pantos \& Bythell, 2010, from the Great Barrier Reef, and Zanclea gallii Montano, Maggioni \& Puce, 2014, from the central Maldives and the northern Red Sea, are both known to live in strict association with the same coral genus, i.e. Acropora Linnaeus, 1758 (Pantos and Bythell 2010; Montano et al. 2015a; Pica et al. in press). Fontana et al. (2012) and Montano et al. (2014) also found Zanclea polyps associated with different Acropora species from Taiwan and Egypt (Dahab), respectively, but they did not perform detailed morphological analyses, leaving those Zanclea colonies unidentified. The two nominal Acropora-associated Zanclea species differ morphologically in the cnidome of the polyp and medusa stages, but no molecular data are available for Z. margaritae. DNA sequences are, so far, available only for Z. gallii from the Maldives and for Zanclea sp. from Taiwan, and molecular phylogenetic analyses have revealed that these two organisms are closely related but genetically distinct (Montano et al. 2015a). Due to the lack of morphological and molecular data, the real diversity of Acropora-associated hydrozoans is still unclear and the presence of other Acroporaassociated Zanclea species cannot be excluded.

Recently, molecular analyses have also shown variable levels of cryptic diversity and host fidelity in other coral-associated invertebrates, and, in some cases, a cryptic radiation similar to Zanclea hydrozoans has been demonstrated (e.g. Gittenberger and Gittenberger 2011; van der Meij et al. 2015 ). For instance, coral endo-parasitic snails belonging to the genus Leptoconchus Rüppell, 1835 have a variable and irregular morphology, and closely related species associated with specific hosts could be detected only through molecular analyses. In this case, DNA sequence alignments were the basis of putative diagnostic analyses, but details of the diagnostic nucleotides were not explained (Gittenberger and Gittenberger 2011). Several other studies have included DNA information in taxonomic descriptions, but, in most cases, in a non-standardised way (reviewed by Goldstein and DeSalle 2011; Renner 2016). Many of the cryptic species detected with this approach still lack a formal description since molecular characters were not presented as diagnostic characters (Jörger and Schröd1 2013). Species delineation methods are now emerging as valuable, rapid tools for cryptic species detection, especially for organisms with few obvious diagnostic morphological characters (Fontaneto et al. 2015), but, when used alone, they do not qualify for character-based species descriptions, as requested by the International Code of Zoological Nomenclature (ICZN, 1999, Article 13.1.1). Character-based approaches, such as the Characteristic Attribute Organization System (CAOS), could, therefore, be used as tools to establish diagnostic characters from DNA sequences to be directly used in species descriptions (Sarkar et al. 2008; Zou et al. 2011; Jörger and Schrödl 2013). This approach has allowed taxonomists to formally describe some cryptic taxa identified with molecular methods at both the species and the genus levels (e.g. Churchill et al. 2014; Johnson et al. 2015; Shipman and Gosliner 2015; Zielske and Haase 2015; Scarpa et al. 2016).

However, in most cases, cryptic species remain nameless because of the lack of additional evidences other than molecular data and, when named, the use of DNA alone could potentially lead to the establishment of a parallel nomenclature, especially if only few molecular markers are investigated. To prevent that, Morard et al. (2016) recently proposed a novel nomenclatural system to be applied to taxa showing a structured genetic diversity occurring below the level of morphospecies, viz. cryptic species. This system allows to classify any genetic data associated to molecular operational taxonomic units (MOTUs) of any level; it should follow the rules of an interim taxonomic system, which are uniqueness of the name employed, stability and proper definition of the given ranks 
(Schindel and Miller 2010); it should be flexible and facilitate the transfer of an MOTU into the formal nomenclature as soon as new relevant evidences are provided. The advantage of this method is that it allows a reliable association of genetic units to any other type of data without creating taxonomical confusion, and permitting their inclusion in future research, such as biodiversity assessments, endemism studies or conservation efforts (Morard et al. 2016).

Here, we provide an updated phylogenetic reconstruction of coral-associated Zanclea hydrozoans, including both morphological and molecular analyses of Acropora-associated specimens collected from four localities in the Red Sea (utilising both existing and new materials). Based on the DNA sequence results, we demonstrate the presence of a cryptic species of coral-associated Zanclea in the Red Sea, identify its diagnostic molecular characters and propose a nomenclature for the Acroporaassociated clade based on the method described by Morard et al. (2016).

\section{Materials and methods}

Fragments of Acropora spp. bearing Zanclea hydrozoans were collected during three separate field surveys conducted in Dahab, Egypt, in October 2013 (Montano et al. 2014), in Eilat, Israel, in May 2014 (Pica et al. in press) and in Al Lith and Thuwal, Saudi Arabia, in December 2015 (new material presented in this study) (Fig. 1). Corals were collected in situ by scuba diving. Fragments of corals bearing hydrozoans were carefully detached from the colony using a chisel, samples were placed into plastic bags underwater and were immediately placed in water tanks after the dive. In the lab, colonies were observed under a Leica EZ4 D stereo microscope and hydroids were carefully detached one by one using syringe needles and micropipettes. Samples were fixed in $4 \%$ formalin and in $99 \%$ ethanol (EtOH) for morphological and molecular characterisations, respectively. Morphology was studied using a Zeiss Axioskop 40 microscope and pictures were taken with a Nikon AW100 camera.

Fig. 1

Map of the Red Sea. The arrowheads indicate the four sampling localities for Zanclea hydroid species

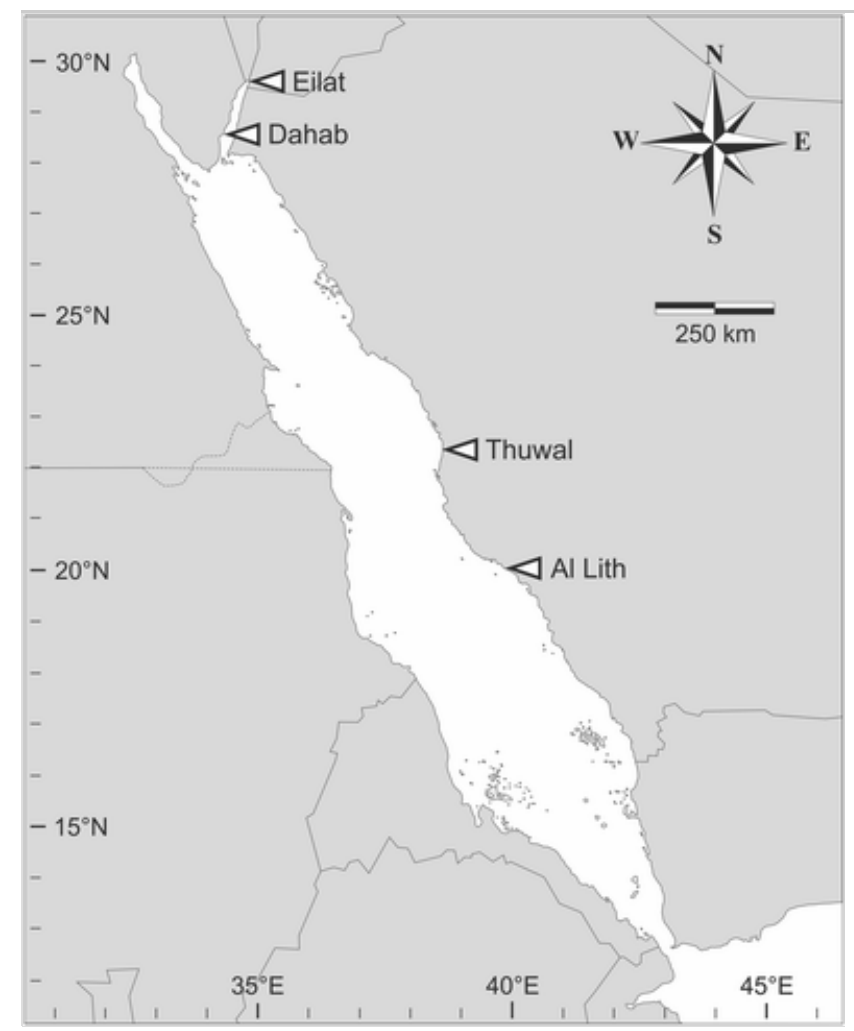


DNA from ethanol-preserved samples was extracted following a protocol modified from Zietara et al. (2000). Five molecular markers were amplified: a portion of the nuclear $28 \mathrm{~S}$ rRNA $(\sim 1700 \mathrm{bp})$, $18 \mathrm{~S}$ rRNA $(\sim 1700 \mathrm{bp})$ and ITS $(\sim 700 \mathrm{bp})$, and a portion of the mitochondrial $16 \mathrm{~S}$ rRNA $(\sim 400$ or $\sim 600 \mathrm{bp}$ ) and COI ( $700 \mathrm{bp})$. The polymerase chain reaction (PCR) assays were set up using the same protocols and primers described by Maggioni et al. (2016), Medlin et al. (1988), Fontana et al. (2012), Cunningham and Buss (1993) and Folmer et al. (1994), respectively. All PCR products were purified with Illustra ExoStar (GE Healthcare, Buckinghamshire) at $37^{\circ}$ for 60 min, followed by $85^{\circ}$ for $15 \mathrm{~min}$, and directly sequenced in forward and reverse directions using an ABI 3730xl DNA Analyzer (Applied Biosystem, Foster City, CA, USA). The sequences were deposited in GenBank with related information on host, locality and voucher number (accession numbers: LN714109, LN714231, LT606967-LT607018). Sequences were aligned with other sequences of coral-associated Zanclea and outgroups retrieved from GenBank and DRYAD (doi: 10.5061/dryad.g0b20 ), using MAFFT 7.110 (Katoh and Standley 2013) with the E-INS-i option. The sequences were combined in a concatenated dataset and PartitionFinder 1.1.1 (Lanfear et al. 2012 ) was used to determine the appropriate partition and molecular models $(16 \mathrm{~S}+\mathrm{COI}: \mathrm{GTR}+\mathrm{I}+\mathrm{G}$; 28S+ITS: GTR+G; 18S: HKY). Bayesian inference (BI) and maximum likelihood (ML) were used to infer phylogenetic relationships for both single-locus and multi-locus datasets. BI analyses were performed using MrBayes 3.2 (Ronquist et al. 2012). Four parallel Markov chain Monte Carlo (MCMC) runs were run for $2 \times 10^{6}$ generations. Trees were sampled every 100th generation and burn-in was set to $25 \%$. ML trees were built with Garli 2.01 (Zwick1 2006). Non-parametric bootstrap values were calculated from 1000 replicates, each based on five heuristic search replicates; the resulting trees were read into the SumTrees 4.0.0 program in the DendroPy 4.0.0 package (Sukumaran and Holder 2010) to obtain bootstrap support values and to map them on the best ML tree. The genetic distances (uncorrected p-distance, 1000 bootstraps) within and among the obtained clades were also estimated for each mitochondrial locus using MEGA 6 (Tamura et al. 2013). Finally, haplotype networks for mitochondrial loci were constructed in Network 4.6.1.2 ( http://www.fluxus-technology.com ) using the median-joining algorithm (Bandelt et al. 1999) and default settings. We decided to interpret the molecular results following the genealogical species concept (Baum and Shaw 1995), according to which a genealogical species is a monophyletic group recovered by multiple molecular markers (Hudson and Coyne 2002). In order to identify diagnostic nucleotides for the newly recovered species, we used the software CAOS (Sarkar et al. 2002, 2008; Bergmann et al. 2009), following the instructions of Jörger and Schrödl (2013, 2014). We considered as diagnostic characters only single pure character attributes, which are single nucleotides present in all members of a clade identified as a species, but absent in members of other clades (Jörger and Schrödl 2014). We then used the nomenclatural system recently proposed by Morard et al. (2016) in order to name the recovered clades. This method is based on the definition of basetypes and the use of their hierarchical phylogenetic structure to define levels of divergence below that of morphospecies. A basetype is defined as a specific DNA substitution pattern observed within a single marker gene, whereas a basegroup is a set of basetypes and constitute the lowest MOTU level. If a gene exists in a unique version, a basegroup will contain only one basetype, otherwise it will contain all pairs of basetypes observed to co-occur in one individual. The genetic variability between the basegroup and the morphospecies is then used to identify intermediate levels at different degrees of divergence, and any of these levels could be theoretically considered a species hypothesis. Similarly to Morard et al. (2016), we propose to define basetypes in hydrozoans by using sequence patterns in a widely used barcode gene in the group, namely the $16 \mathrm{~S}$ rRNA.

\section{Results}

Morphological observation of Red Sea Acropora-associated hydroids revealed morphology 
consistent with the description of Zanclea gallii in all specimens. No morphometric differences were found among all the examined polyps (see 'Taxonomic section'). However, according to molecular analyses, specimens from the Red Sea formed a Zanclea clade divergent from the Indian Ocean clade and, based on these results, we characterise the Red Sea group as a cryptic species of Zanclea gallii.

\section{Molecular results}

The total alignments of the concatenated dataset was $5072 \mathrm{bp}$ long and included representatives of all the coral-associated Zanclea clades detected by Fontana et al. (2012) and Montano et al. (2015a, b). According to the five-loci tree as well as all single-locus analyses, the coral-associated Zanclea clade wasis monophyletic, with high support values (Fig. 2a, Figs. S1-S5). Mitochondrial markers showed the highest resolution of molecular lineages within the scleractinian-associated Zanclea clade (Figs. S1 and S2), and the same clades as in Montano et al. (2015b) wereare recovered. All hydrozoans associated with Acropora corals from different localities formed a highly supported monophyletic lineage, which comprisesd specimens from the Maldives, Taiwan and the Red Sea (Fig. 2a). In addition, the Acropora-associated clade showsed a further genetic diversification (Fig. 2a, b), and hydroids collected from the three different areas formed three distinct well-supported subclades.

\section{Fig. 2}

Molecular diversity of coral-associated Zanclea. a Bayesian phylogenetic hypothesis of coralassociated Zanclea hydrozoans based on the concatenated dataset of COI, 16S rRNA, 18S rRNA, 28S rRNA and ITS genes. Clade support values are posterior probabilities from Bayesian inference and bootstrap values from maximum likelihood analyses, respectively. Different clades of Acroporaassociated hydrozoans are highlighted with different colours and are named according to the molecular nomenclature applied to the $16 \mathrm{~S}$ rRNA tree. The node supporting the scleractinian-associated Zanclea clade is highlighted in red. b, c Most parsimonious median-joining networks of Zanclea associated with Acropora inferred from mitochondrial genes 16S rRNA (b) and COI (c). The size of the circles is proportional to the frequencies of specimens sharing the same haplotype. The colours of the circles refer to clades found in $\mathbf{a}$ 

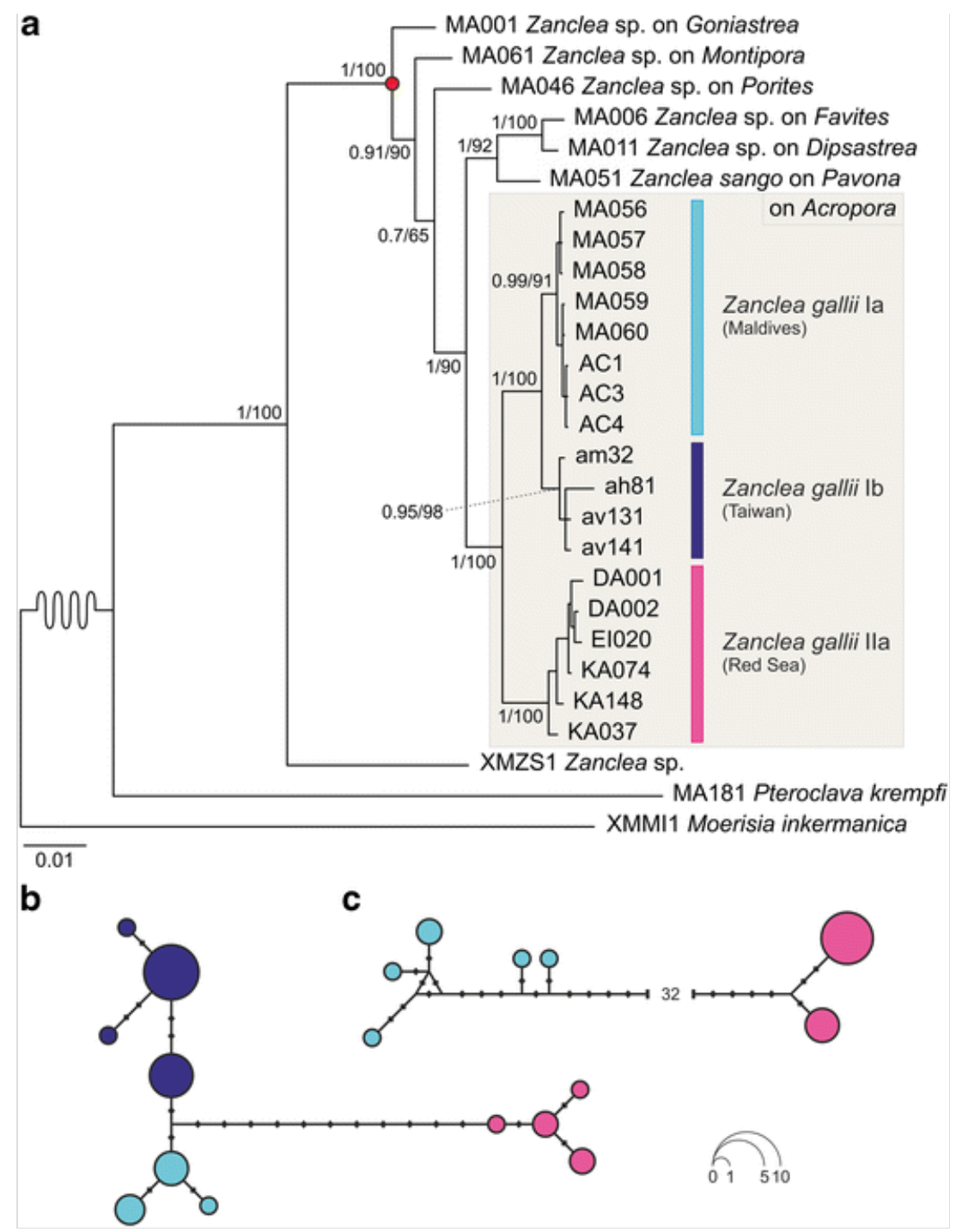

According to this genetic structure, we used the 16S rRNA tree to identify two levels of divergence below the morphospecies level (Fig. S1) and we used them to apply to the group the nomenclatural system proposed by Morard et al. (2016) (Fig. 2). Level one (indicated with Roman numerals) corresponds to a monophyletic cluster of intermediate-level MOTUs and likely represents at least the level of species; level two (indicated with lowercase letters) is a monophyletic cluster of basegroups and likely corresponds to the level of species or population.

Specimens growing on Acropora from the Maldives correspond to the type population of Zanclea gallii (Zanclea gallii Ia) and form the sister clade of Zanclea sp. from Taiwan, here named Zanclea gallii $\mathrm{Ib}$. These two groups cluster in a monophyletic lineage and are separated by low genetic distances for 16S rRNA (Table 1), whereas there are no available COI sequences for Taiwanese samples. A third monophyletic clade formed by all the sequences from the Red Sea obtained in this study and corresponding to Zanclea gallii IIa wasis highly divergent from the other two Acroporaassociated clades and the genetic distances between Zanclea from the Red Sea and Zanclea from the Maldives and Taiwan wereare high, with a mean of $4 \%$ for $16 \mathrm{~S}$ rRNA and $8 \%$ for COI (Table 1 ). Conversely, intra-clade distances whereare generally low, ranging from $0.2 \%$ for $16 \mathrm{~S}$ rRNA sequences of Maldivian specimens to $0.8 \%$ for COI sequences of samples from the Red Sea. A total of seven and 11 haplotypes for COI and 16S rRNA, respectively, were obtained from Zanclea associated with Acropora; median-joining networks for each marker are shown in Fig. 2 b, c. Both networks are were congruent with the phylogenetic reconstruction and they wereare similar to each other, with the only exception being the absence of COI sequences of Zanclea from Taiwan. Zanclea 
specimens from the Red Sea wereare separated from other clades by 12 substitutions in the $16 \mathrm{~S}$ rRNA network and 41 substitutions in the COI network, whereas Maldivian and Taiwanese specimens wereare separated by two substitutions in 16S rRNA network. Interpreting these genetic results within the framework of the genealogical species concept, all the specimens of Acroporaassociated Zanclea hydrozoans from the Red Sea constitute an independent lineage ascribable to an independent species and CAOS analysis identified 16 diagnostic positions in the 16S rRNA and COI sequences for this group (Table 2).

\section{Table 1}

Pairwise comparisons of genetic distance (uncorrected p-distance in \%) within and between Zanclea clades associated with Acropora, based on the mitochondrial genes 16S rRNA and COI. Standard deviations are in parentheses

\begin{tabular}{|l|l|l|l|l|l|l|}
\hline & \multicolumn{2}{|c|}{ Zanclea gallii Ia } & \multicolumn{2}{c|}{ Zanclea gallii Ib } & \multicolumn{2}{c|}{ Zanclea gallii IIa } \\
\hline & 16S rRNA & COI & 16S rRNA & COI & 16S rRNA & COI \\
\hline Zanclea gallii Ia & $0.2(0.2)$ & $0.3(0.1)$ & & & & \\
\hline Zanclea gallii $\mathrm{Ib}$ & $1.1(0.5)$ & n.c. & $0.3(0.3)$ & n. c. & & $0.8(0.2)$ \\
\hline Zanclea gallii $\mathrm{IIa}$ & $4.1(1.1)$ & $8.1(1.3)$ & $4.4(1.1)$ & n. c. & $0.3(0.2)$ & \\
\hline
\end{tabular}

\section{Table 2}

Molecular diagnostic characters of Zanclea gallii IIa

\begin{tabular}{|c|c|}
\hline Marker & Diagnostic characters with position in alignment (in holotype-reference sequence) \\
\hline $\mathrm{COI}$ & $\begin{array}{l}20 \text { (48), G; } 38 \text { (66), G; } 54 \text { (82), T; } 71 \text { (99), T; } 98 \text { (126), G; } 143 \text { (171), C; } 158 \text { (186), G; } 242 \\
(270), \mathrm{C} ; 308 \text { (336), T; } 374 \text { (402), G; } 389 \text { (417), G; } 503 \text { (531), C; } 635 \text { (663), G }\end{array}$ \\
\hline $\begin{array}{l}16 \mathrm{~S} \\
\text { rRNA }\end{array}$ & 161 (297), T; 203 (339), G; 233 (369), G \\
\hline
\end{tabular}

\section{Taxonomic section}

Phylum Cnidaria Verrill, 1865

Class Hydrozoa Owen, 1843

Order Anthoathecata Cornelius, 1992

Family Zancleidae Russell, 1953

Genus Zanclea Gegenbaur, 1856

Zanclea gallii IIa

Materials examined Sample KA037, Abu Latt Island, Al Lith, Saudi Arabia (19.946 N, 40.151 E), depth: $8 \mathrm{~m}, 11$ December 2015. Colony growing on Acropora sp. preserved in 99\% EtOH and 6\% formalin. GenBank accession numbers for reference DNA sequences are LT607016 for COI, LT607008 for 16S rRNA, LT606979 for 18S rRNA, LT606992 for 28S rRNA and LT607002 for ITS. - Sample KA074, Tahla Reef, Thuwal, Saudi Arabia (22.274 N, 39.047 E), depth: 14 m, 15 December 2015, preserved in 99\% EtOH. - Sample KA148, Abu Geisha Reef, Thuwal, Saudi Arabia (22.427 N, 39.051 E), depth: 4 m, 16 December 2015, preserved in 99\% EtOH. - Sample EA003 
(DA001), Dahab, Egypt (28.467 N, 34.500 E), October 2013, preserved in 99\% EtOH. - Sample EA004 (DA002), Dahab, Egypt (28.467 N, 34.500 E), October 2013, preserved in 99\% EtOH. Sample EAC1, Dahab, Egypt (28.467 N, 34.500 E), November 2013, preserved in 99\% EtOH. Sample HYD_57 (EI020), Eilat, Israel (29.502 N, 34.917 E), 12 May 2014, preserved in 99\% EtOH.

Morphological description Colonies live in association with the scleractinians Acropora spp. (Fig. 3). Gastrozooids arise from coral tissues, mainly near corallites and sometimes between corallites (Fig. 3a). Coral tissues surround the base of hydranths with collar-like elevations (Fig. 3b). Perisarc around the polyp base was not observed. Gastrozooids are cylindrical and range from 0.7 to $1.4 \mathrm{~mm}$ in height (Fig. 3b, c). The hypostome is surrounded by five capitate tentacles (diameter of capitula 40-45 $\mu \mathrm{m}$ ), whereas the body of the hydranth is surrounded by 15-25 scattered capitate tentacles (diameter of capitula 30-35 $\mu \mathrm{m}$ ) (Fig. 3c). Up to two medusa buds at different stages of maturation grow at the base of gono-gastrozooids (Fig. 3c, d). The cnidome is composed of stenoteles of two sizes classes $(10-11 \times 9-10 \mu \mathrm{m}$ and 6-7 $\times 5-6 \mu \mathrm{m})$, which are confined in the capitula (Fig. 3e). Living hydrants are transparent, with a white hypostome. Dactylozooids and medusae were not observed. CAOS analysis identified 13 diagnostic positions in COI and three diagnostic nucleotides in 16S rRNA (see Table 2 for the complete list of diagnostic positions).

Fig. 3

Zanclea gallii IIa. a In situ photograph of a colony associated with Acropora sp. (modified from Montano et al. 2014). b Gastrozooid showing the basal collar of tissue produced by the acroporid host. c Micrograph of a detached gono-gastrozooid (modified from Montano et al. 2014). d Close-up of two medusa buds at different stages of maturation. e Cnidome of the polyp, composed of stenoteles of two sizes. f Colony arising from a recently bleached Acropora sp. Scale bars: a, f 2 mm; b, c $100 \mu \mathrm{m}$; d $50 \mu \mathrm{m} ;$ e $5 \mu \mathrm{m}$
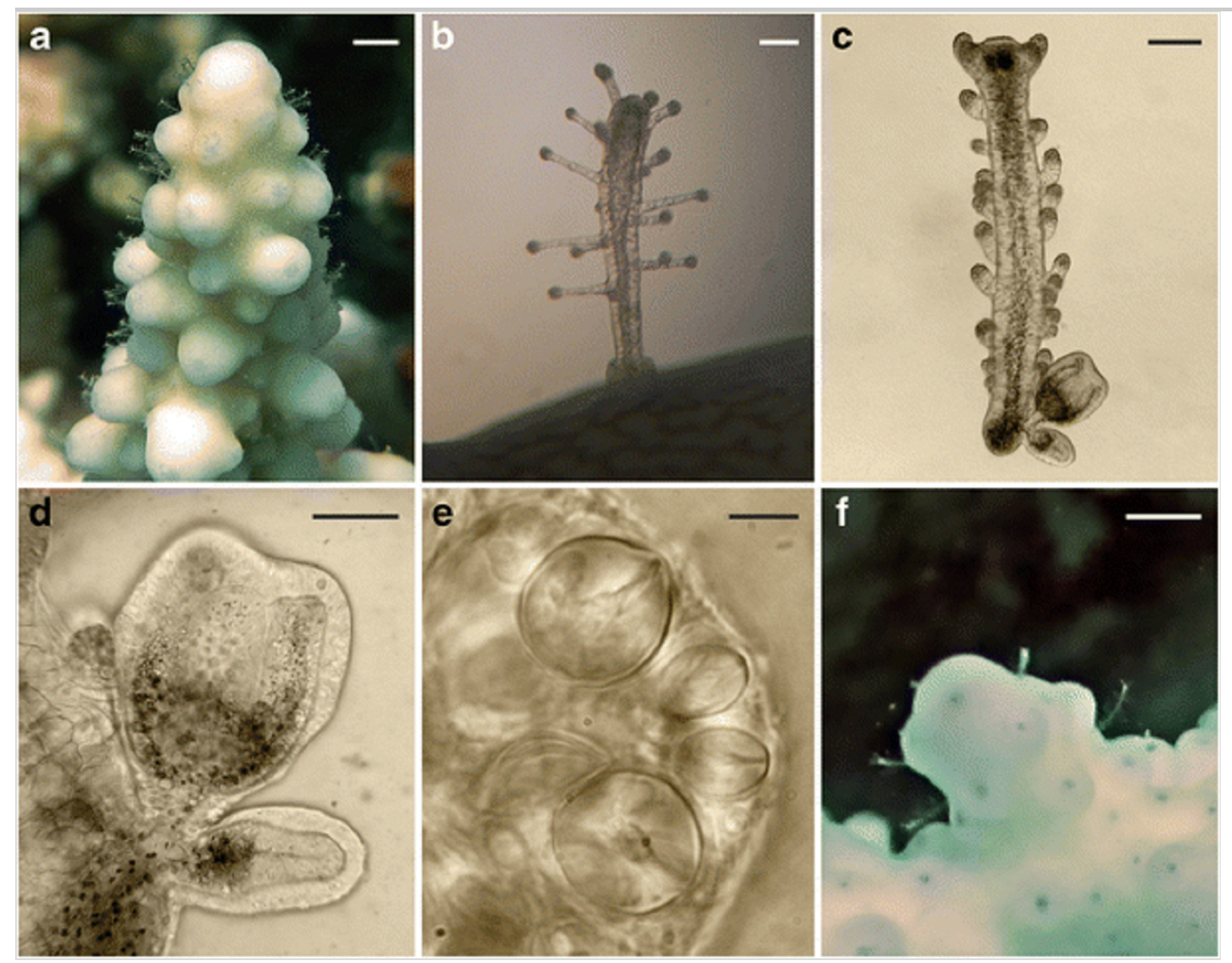

Habitat, relationship with the host and distribution Zanclea gallii IIa was found at depths ranging from 5 to $27 \mathrm{~m}$ (this study; Pica et al. in press) and living in association with corals belonging to the genus Acropora. Zanclea colonies were found on both healthy and completely bleached corals 
(Fig. 3f).

The known geographic range for this species extends from the northern tip of the Red Sea (Eilat, Israel, in the Gulf of Aqaba) to the south-central Red Sea (Al Lith).

Remarks Specimens from Dahab were previously identified as Zanclea polyps by Montano et al. (2014), whereas Pica et al. (in press) considered the specimens from Eilat as belonging to Zanclea gallii. Indeed, our description of the polyp stage of Zanclea gallii IIa is completely consistent with the description of $Z$. gallii Ia from the Maldives and both the general morphology and the morphometric measurements are almost identical in the two species. Slight differences are detectable in the size range of large stenoteles (11-15 $\times 10-14 \mu \mathrm{m}$ in Maldivian Z. gallii) and in the diameter of capitula (about $10 \mu \mathrm{m}$ bigger in Maldivian $Z$. gallii), but these minor variations are not enough to morphologically discriminate between the two species reliably. By contrast, polyps of the other Acropora-associated species from Australia, i.e. Zanclea margaritae, are easily recognisable thanks to the presence of isorhiza capsules. Dactylozooids in Z. margaritae are highly retractile and can retract almost completely in host tissues when disturbed (Pantos and Bythell 2010). In Maldivian $Z$. gallii Ia colonies, they are very rare and only in situ pictures are available to document their presence (Montano et al. 2015a). For these reasons, the fact that dactylozooids were not observed in $Z$. galli IIa might be due to the cryptic nature of these specialised polyps and uncertainties remain about the polymorphic or monomorphic state of the species. Zanclea gallii Ia and Z. margaritae differ in the medusa stage for the presence of mastigophores in the exumbrella of the latter. Throughout our surveys, we never found mature medusa buds, so morphological observations of newly liberated medusa were, therefore, not possible for $Z$. gallii IIa. However, despite the conserved morphology and the missing medusa data, the distinction can be easily made based on distribution data and DNA sequences, and we, therefore, consider Z. gallii Ia from the Maldives and Z. gallii IIa from the Red Sea as independent species.

\section{Discussion}

Few hydroid species are found in strict association with other members of Cnidaria, and most of them are epibiont of octocorals (Puce et al. 2008a; Bo et al. 2011; Maggioni et al. 2016; Montano et al. 2016b). The hydrozoan genus Zanclea comprises species associated with a wide range of hosts, including both octocorals and hexacorals (Boero et al. 2000; Puce et al. 2008b). In particular, the species Zanclea timida Puce, Di Camillo \& Bavestrello, 2008 is known to grow epibiotically on the octocoral Paratelesto sp. (Puce et al. 2008b), whereas Zanclea gilii Boero, Bouillon \& Gravili, 2000, Zanclea sango Hirose \& Hirose 2011, Z. margaritae and Zanclea gallii are symbionts of scleractinian corals (Boero et al. 2000; Pantos and Bythell 2010; Hirose and Hirose 2012; Montano et al. 2015a). Describing the first species of Zanclea associated with scleractinians, i.e. Z. gilii, Boero et al. (2000) hypothesised that coral-associated Zanclea hydroids might have had a radiation similar to bryozoan-associated Zanclea species, but they stated that they found just one species, despite inspecting several corals. Subsequent surveys confirmed this hypothesis, with the description of three other species associated with scleractinian corals from different localities (Pantos and Bythell 2010; Hirose and Hirose 2012; Montano et al. 2015a). Moreover, molecular analyses revealed the existence of several other lineages identified as Zanclea spp. and associated with 11 coral genera from central Maldives (Montano et al. 2015b). These lineages showed a great genetic diversity and might, therefore, be ascribable to independent species, some of which are morphologically indistinguishable, at least regarding the polyp stage (Montano et al. 2015b). Although these molecular lineages showed different levels of host-specificity, all clades were specifically associated with a single coral genus or group of genera, with no overlap of two or more lineages on the same coral host. Fontana et al. (2012) analysed the molecular diversity of Zanclea 
hydroids associated with 14 Acropora species from Taiwan, finding a very low genetic diversity among all the Zanclea specimens, thus hypothesising a genus-specific association of a single Zanclea species. However, two coral-associated Zanclea nominal species, i.e. Z. margaritae and Z. gallii, were described in association with the same acroporid host from other localities (Pantos and Bythell 2010; Montano et al. 2015a), suggesting a more complex situation for Acropora-associated hydroids. Both host-specificity and other factors, such as geography, might have, therefore, shaped the genetic diversity of Zanclea growing on Acropora, and this scenario is confirmed by the present detection of Zanclea gallii IIa. Previously collected Acropora-associated Zanclea from Dahab were formerly unidentified (Montano et al. 2014), and colonies from Eilat were identified as Z. gallii (Pica et al. in press) due to their resemblance with the latter, but according to our molecular analyses, they both belong to a divergent independent lineage. Even though molecular investigations clearly separated Z. gallii IIa and Z. gallii in two distinct and divergent clades, also supported by high mitochondrial genetic distances, our morphological and morphometric investigations of the polyps did not allow any distinction between them.

The three Acropora-associated species appear at this stage to have non-overlapping geographic distributions: Z. gallii Ia is found in Maldivian reefs, Z. margaritae in the Great Barrier Reef and $Z$. gallii IIa in the Red Sea. Sequences of Zanclea growing on Acropora from Taiwan analysed by Fontana et al. (2012) are highly divergent from Z. gallii IIa but not from Z. gallii Ia, and they form a monophyletic clade with the latter. Comparing genetic distances and haplotype networks for the three Zanclea groups, Z. gallii IIa was clearly separated from the other two, whereas the distinction between Z. gallii Ia and Zanclea gallii Ib was not so apparent and doubts remain about their conspecificity. Since no exhaustive molecular data and no morphological data are available for Taiwanese Zanclea, these specimens might constitute a divergent population of Z. gallii Ia, $Z$. margaritae or another independent species and further studies are needed to address this question. Moreover, the phylogenetic position of Z. margaritae is still to be assessed since it has not been included yet in molecular analyses, and future molecular studies might theoretically identify one of the already known genetic lineages with this species.

Although the cnidome composition separates Z. margaritae from all other coral-associated hydrozoans, this species shares several morphological traits with Z. gallii Ia and Z. gallii IIa, notably the absence of euryteles and possibly the loss of perisarc (Pantos and Bythell 2010; Pantos and Hoegh-Guldberg 2011; Montano et al. 2015a). These characteristics suggest a highly integrated and dynamic relationship between hydroids and their acroporid hosts, in particular because the absence of perisarc allows the direct anchoring of hydranths on coral skeleton through desmocytes (Puce et al. 2002; Pantos and Hoegh-Guldberg 2011). Conversely, in other coral-associated clades, the presence of the perisarc, the low host-specificity or both these conditions might indicate a less specialised host-symbiont interaction (Hirose and Hirose 2012; Montano et al. 2015b), but this scenario needs to be confirmed through a more comprehensive survey of all coral-associated clades.

Despite the hypothesised more intimate relationship between Zanclea and Acropora, this coral genus is, so far, the only one found in association with more than one Zanclea species or molecular clade. The high diversity of Acropora-associated Zanclea might be explained by its biogeography, especially regarding $Z$. gallii IIa, since this species was found exclusively in the Red Sea, a biodiversity and endemicity hotspot (Hughes et al. 2002). The Red Sea is isolated from the Indian Ocean by a narrow and shallow entrance (Eshel et al. 1994; Bailey 2010) and is characterised by heterogeneous environmental conditions of both inner and bordering waters, including salinity, temperature and productivity fluctuations (Sofianos and Johns 2003; Raitsos et al. 2013). These unusual environmental conditions, along with a peculiar geological history, likely contribute to the high number of endemic species (see DiBattista et al. 2016a, b for reviews) and might have played 
a role also in the speciation of $Z$. gallii IIa, even though further investigations in the southern Red Sea, the Gulf of Aden and nearby areas are needed to fully assess the endemicity of this species. Another possible explanation of the Acropora-related Zanclea diversity could refer to the ecological and evolutionary traits of Acropora corals. Acropora species are characterised by fast growth rates and are more prone to stressors; for example, Acroporathey are more susceptible to bleaching than slow-growing massive species (e.g. Marshall and Baird 2000; Loya et al. 2001; Montano et al. 2010 ), including within the Red Sea (Furby et al. 2013). However, this genus has been seen to constitute one of the major taxonomic components of recruits to settlement plates (Sammarco and Carleton 1981; Wallace and Bull 1982; Wallace 1983; Fisk and Harriott 1990; Harriott 1992), to dominate in some cases coral assemblages recovering from damage (Pearson 1981) and to regenerate from fragments (Wallace 1985). These characteristics suggest an important early successional role for this genus, with some species demonstrating high population turnover rates (e.g. Guzner et al. 2007). The ecological nature of the Acropora genus might have influenced the speciation rate of its specifically associated organisms, such as Zanclea hydrozoans.

Throughout our surveys, we found Z. gallii IIa on both healthy and bleached Acropora corals. Similar situations were found for Z. margaritae and Z. gallii Ia (Pantos and Bythell 2010; Montano et al. 2015a). Even if some hypotheses have been formulated, the nature of coral-Zanclea symbioses is still unclear, and different species might have different effects in both unaltered and stressed conditions. For these reasons, the clarification of the systematics of all coral-associated hydroids and the characterisation of morphological and ecological traits that could play a role in their interaction with scleractinian corals are fundamental steps to better understanding this symbiosis. In particular, given the lack of informative morphological characters at this stage, the use of diagnostic molecular characters and a flexible molecular nomenclature are efficient tools to refer to cryptic or pseudocryptic species. This allows to include in further studies taxa that could otherwise be hardly and confusingly considered, and make possible the transfer of knowledge across disciplines. Moreover, this nomenclatural system easily allows the transfer of a given genetic group to formal nomenclature, as soon as it is diagnosed with other lines of evidence (Morard et al. 2016), such as new morphological characters or ecological information. The detection and naming of cryptic species identified using molecular techniques is, therefore, an important step forward to better characterise the biodiversity, the level of endemism and the diversification processes of a given area, especially in case of remote and isolated areas, such as the Red Sea. Hence, further studies are needed in order to assess the diversity, evolution and ecology of coral-associated Zanclea from different localities and growing on different hosts, since the genetic diversification of these organisms has been shown here to be related to both host-specificity and biogeography.

\section{Acknowledgements}

This research was undertaken in accordance with the policies and procedures of the King Abdullah University of Science and Technology (KAUST). Permissions relevant for KAUST to undertake the research have been obtained from the applicable governmental agencies in the Kingdom of Saudi Arabia. The authors wish to thank the members of the Reef Ecology Lab at King Abdullah University of Science and Technology and, in particular, Tullia Terraneo (KAUST) and Malek Amr Gusti (KAUST) for logistic support. Many thanks go to the staff of the iDive and Open Ocean Science Centre in Dahab, especially to Inga Dehnert and Hans Lange for their help in the field activities. We also want to thank all the staff of the Interuniversity Institute for Marine Sciences (IUI) in Eilat for their logistic support. Finally, we thank the two anonymous reviewers for their constructive comments. This project was partly supported by funding from KAUST (award \# FCC/1/1973-07 and baseline research funds to MLB) and University of Milano-Bicocca (baseline research fund to PG). The samples from Eilat were collected during the project 'HyDRa' 
(ASSEMBLE grant no. 227799).

\section{Electronic supplementary material}

Below are the links to the electronic supplementary material.

\section{Fig. S1}

(PDF $19 \mathrm{~kb})$

\section{Fig. S2}

(PDF $17 \mathrm{~kb})$

\section{Fig. S3}

(PDF $16 \mathrm{~kb})$

\section{Fig. S4}

(PDF $17 \mathrm{~kb})$

\section{Fig. S5}

(PDF $16 \mathrm{~kb})$

\section{References}

Alamaru A, Brokovich E, Loya Y (2016) Four new species and three new records of benthic ctenophores (Family: Coeloplanidae) from the Red Sea. Mar Biodivers 46:261-279. doi: $10.1007 / \mathrm{s} 12526-015-0362-4$

Appeltans W, Ahyong ST, Anderson G et al (2012) The magnitude of global marine species diversity. Curr Biol 22:2189-2202. doi: 10.1016/j.cub.2012.09.036

Arrigoni R, Berumen ML, Huang D, Terraneo TI, Benzoni F (2016) Cyphastrea (Cnidaria: Scleractinia: Merulinidae) in the Red Sea: phylogeny and a new reef coral species. Invertebr Syst. doi: $10.1071 /$ IS16035

Bailey G (2010) The Red Sea, coastal landscapes, and hominin dispersals. In: Petraglia MD, Rose JI (eds) The evolution of human populations in Arabia. Springer, Dordrecht, pp 15-37. doi: 10.1007/978-90-481-2719-1_2

Bandelt HJ, Forster P, Röhl A (1999) Median-joining networks for inferring intraspecific phylogenies. Mol Biol Evol 16:37-48. doi: 10.1093/oxfordjournals.molbev.a026036

Baum DA, Shaw KL (1995) Genealogical perspectives on the species problem. In: Hoch PC, Stephenson AG (eds) Experimental and molecular approaches to plant biosystematics. Monographs in systematics, vol 53. Missouri Botanical Garden, St. Louis, pp 289-303

Bergmann T, Hadrys H, Breves G, Schierwater B (2009) Character-based DNA barcoding: a 
superior tool for species classification. Berl Munch Tierarztl Wochenschr 122:446-450. doi: $10.2376 / 0005-9366-122-446$

Berumen ML, Hoey AS, Bass WH et al (2013) The status of coral reef ecology research in the Red Sea. Coral Reefs 32:737-748. doi: 10.1007/s00338-013-1055-8

Bo M, Di Camillo CG, Puce S et al (2011) A tubulariid hydroid associated with anthozoan corals in the Mediterranean Sea. Ital J Zool 78:487-496. doi: 10.1080/11250003.2011.568015

Boero F, Bouillon J, Gravili C (2000) A survey of Zanclea, Halocoryne and Zanclella (Cnidaria, Hydrozoa, Anthomedusae, Zancleidae) with description of new species. Ital J Zool 67:93-124. doi: $10.1080 / 11250000009356301$

Bouchet P, Lozouet P, Maestrati P, Heros V (2002) Assessing the magnitude of species richness in tropical marine environments: exceptionally high numbers of molluscs at a New Caledonia site. Biol J Linn Soc 75:421-436. doi: 10.1046/j.1095-8312.2002.00052.x

Bouwmeester J, Benzoni F, Baird AH, Berumen ML (2015) Cyphastrea kausti sp. n. (Cnidaria, Anthozoa, Scleractinia), a new species of reef coral from the Red Sea. ZooKeys 496:1-13. doi: 10.3897/zookeys.496.9433

AQ1

Campbell AC (1987) Echinoderms of the Red Sea. Pergamon Press, Oxford

Castresana J (2000) Selection of conserved blocks from multiple alignments for their use in phylogenetic analysis. Mol Biol Evol 17:540-552. doi: 10.1093/oxfordjournals.molbev.a026334 AQ2

Churchill CK, Valdés Á, Foighil DÓ (2014) Molecular and morphological systematics of neustonic nudibranchs (Mollusca: Gastropoda: Glaucidae: Glaucus), with descriptions of three new cryptic species. Invertebr Syst 28:174-195. doi: 10.1071/IS13038

Cunningham CW, Buss LW (1993) Molecular evidence for multiple episodes of paedomorphosis in the family Hydractiniidae. Biochem Syst Ecol 21:57-69. doi: 10.1016/0305-1978(93)90009-G

DiBattista JD, Howard Choat J, Gaither MR et al (2016a) On the origin of endemic species in the Red Sea. J Biogeogr 43:13-30. doi: 10.1111/jbi.12631

DiBattista JD, Roberts MB, Bouwmeester J et al (2016b) A review of contemporary patterns of endemism for shallow water reef fauna in the Red Sea. J Biogeogr 43:423-439. doi: $10.1111 /$ jbi.12649

Edgar RC (2004) MUSCLE: multiple sequence alignment with high accuracy and high throughput. Nucleic Acids Res 32:1792 1797. doi: 10.1093/nar/gkh340 AQ3

Eshel G, Cane MA, Blumenthal MB (1994) Modes of subsurface, intermediate, and deep water renewal in the Red Sea. J Geophys Res Oceans 99:15941-15952. doi: 10.1029/94JC01131

Fisk DA, Harriott VJ (1990) Spatial and temporal variation in coral recruitment on the Great 
Barrier Reef: implications for dispersal hypotheses. Mar Biol 107:485-490. doi: 10.1007/BF01313433

Folmer O, Black M, Hoeh W, Lutz R, Vrijenhoek R (1994) DNA primers for amplification of mitochondrial cytochrome $c$ oxidase subunit I from diverse metazoan invertebrates. Mol Mar Biol Biotechnol 3:294-299

Fontana S, Keshavmurthy S, Hsieh HJ et al (2012) Molecular evidence shows low species diversity of coral-associated hydroids in Acropora corals. PLoS One 7:e50130. doi: 10.1371/journal.pone.0050130

Fontaneto D, Flot JF, Tang CQ (2015) Guidelines for DNA taxonomy, with a focus on the meiofauna. Mar Biodivers 45:433-451. doi: 10.1007/s12526-015-0319-7

Furby KA, Bouwmeester J, Berumen ML (2013) Susceptibility of central Red Sea corals during a major bleaching event. Coral Reefs 32:505-513. doi: 10.1007/s00338-012-0998-5

Gegenbaur C (1856) Versuch eines Systemes der Medusen, mit Beschreibung neuer oder wenig gekannter Formen; zugleich ein Beitrag zur Kenntniss der Fauna des Mittelmeeres. Z Wiss Zool $8: 202-273$

Gittenberger A, Gittenberger E (2011) Cryptic, adaptive radiation of endoparasitic snails: sibling species of Leptoconchus (Gastropoda: Coralliophilidae) in corals. Org Divers Evol 11:21-41. doi: 10.1007/s13127-011-0039-1

Goldstein PZ, DeSalle R (2011) Integrating DNA barcode data and taxonomic practice: determination, discovery, and description. Bioessays 33:135-147. doi: 10.1002/bies.201000036

Gravili C, Camillo CG, Piraino S, Boero F (2013) Hydrozoan species richness in the Mediterranean Sea: past and present. Mar Ecol 34:41-62. doi: 10.1111/maec.12023

Guinot DA (1967) La faune carcinologique (Crustacea Brachyura) de l'océan Indien occidental et de la Mer Rouge. Catalogue, remarques biogéographiques et bibliographie. Mém Inst Fondam Afrique Noire 77:235-252

Guzner B, Novoplansky A, Chadwick NE (2007) Population dynamics of the reef-building coral Acropora hemprichii as an indicator of reef condition. Mar Ecol Prog Ser 333:143-150. doi: 10.3354/meps333143

Harriott VJ (1992) Recruitment patterns of scleractinian corals in an isolated sub-tropical reef system. Coral Reefs 11:215-219. doi: 10.1007/BF00301996

Hirose M, Hirose E (2012) A new species of Zanclea (Cnidaria: Hydrozoa) associated with scleractinian corals from Okinawa, Japan. J Mar Biol Assoc UK 92:877-884. doi: $10.1017 / \mathrm{S} 0025315411001238$

Hudson RR, Coyne JA (2002) Mathematical consequences of the genealogical species concept. Evolution 56:1557-1565. doi: 10.1554/0014-3820(2002)056[1557:MCOTGS]2.0.CO;2

Hughes TP, Bellwood DR, Connolly SR (2002) Biodiversity hotspots, centres of endemicity, and 
the conservation of coral reefs. Ecol Lett 5:775-784. doi: 10.1046/j.1461-0248.2002.00383.x

Johnson SB, Warén A, Tunnicliffe V et al (2015) Molecular taxonomy and naming of five cryptic species of Alviniconcha snails (Gastropoda: Abyssochrysoidea) from hydrothermal vents. Syst Biodivers 13:278-295. doi: 10.1080/14772000.2014.970673

Jörger KM, Schrödl M (2013) How to describe a cryptic species? Practical challenges of molecular taxonomy. Front Zool 10:59. doi: 10.1186/1742-9994-10-59

Jörger KM, Schrödl M (2014) How to use CAOS software for taxonomy? A quick guide to extract diagnostic nucleotides or amino acids for species descriptions. Spixiana 37:21-26

Katoh K, Standley DM (2013) MAFFT multiple sequence alignment software version 7: improvements in performance and usability. Mol Biol Evol 30:772-780. doi: 10.1093/molbev /mst010

Knowlton N (2000) Molecular genetic analyses of species boundaries in the sea. Hydrobiologia 420:73-90. doi: 10.1023/A:1003933603879

Lanfear R, Calcott B, Ho SY, Guindon S (2012) PartitionFinder: combined selection of partitioning schemes and substitution models for phylogenetic analyses. Mol Biol Evol 29:1695-1701. doi: 10.1093/molbev/mss020

Linnaeus C (1758) Systema Naturae per regna tria naturae, secundum classes, ordines, genera, species, cum characteribus, differentiis, synonymis, locis. Editio decima, reformata. Holmiae, Stockholm

Loya Y, Sakai K, Yamazato K, Nakano Y, Sambali H, Van Woesik R (2001) Coral bleaching: the winners and the losers. Ecol Lett 4:122-131. doi: 10.1046/j.1461-0248.2001.00203.x

Maddison WP, Maddison DR (2016) Mesquite: a modular system for evolutionary analysis. Version 3.10. Home page at: http://mesquiteproject.org . Accessed 31 July 2016 AQ4

Maggioni D, Montano S, Seveso D, Galli P (2016) Molecular evidence for cryptic species in Pteroclava krempfi (Hydrozoa, Cladocorynidae) living in association with alcyonaceans. Syst Biodivers 14:484-493. doi: 10.1080/14772000.2016.1170735

Marshall PA, Baird AH (2000) Bleaching of corals on the Great Barrier Reef: differential susceptibilities among taxa. Coral Reefs 19:155-163. doi: 10.1007/s003380000086

Medlin L, Elwood HJ, Stickel S, Sogin ML (1988) The characterization of enzymatically amplified eukaryotic 16S-like rRNA-coding regions. Gene 71:491-499. doi: 10.1016/0378-1119(88)90066-2

Millard NAH, Bouillon J (1974) A collection of hydroids from Moçambique, East Africa. Ann S Afr Mus 65:1-40

Montano S, Seveso D, Galli P, Obura DO (2010) Assessing coral bleaching and recovery with a colour reference card in Watamu Marine Park, Kenya. Hydrobiologia 655:99-108. doi: 
Montano S, Maggioni D, Galli P, Seveso D, Puce S (2013) Zanclea-coral association: new records from Maldives. Coral Reefs 32:701. doi: 10.1007/s00338-013-1023-3

Montano S, Galli P, Maggioni D, Seveso D, Puce S (2014) First record of coral-associated Zanclea (Hydrozoa, Zancleidae) from the Red Sea. Mar Biodivers 44:581-584. doi: 10.1007/s12526-014-0207-6

Montano S, Arrigoni R, Pica D, Maggioni D, Puce S (2015a) New insights into the symbiosis between Zanclea (Cnidaria, Hydrozoa) and scleractinians. Zool Scr 44:92-105. doi: 10.1111/zsc. 12081

Montano S, Maggioni D, Arrigoni R, Seveso D, Puce S, Galli P (2015b) The hidden diversity of Zanclea associated with scleractinians revealed by molecular data. PLoS One 10:e0133084. doi: 10.1371/journal.pone. 0133084

Montano S, Seveso D, Galli P, Puce S, Hoeksema BW (2015c) Mushroom corals as newly recorded hosts of the hydrozoan symbiont Zanclea sp. Mar Biol Res 11:773-779. doi: $10.1080 / 17451000.2015 .1009467$

Montano S, Galli P, Hoeksema BW (2016a) First record from the Atlantic: a Zancleascleractinian association at St. Eustatius, Dutch Caribbean. Mar Biodivers 1-2. doi: $10.1007 / \mathrm{s} 12526-015-0432-7$

Montano S, Maggioni D, Galli P, Hoeksema BW (2016b) A cryptic species in the Pteroclava krempfi species complex (Hydrozoa, Cladocorynidae) revealed in the Caribbean. Mar Biodivers 1-7. doi: 10.1007/s12526-016-0555-5

Morard R, Escarguel G, Weiner AK et al (2016) Nomenclature for the nameless: a proposal for an integrative molecular taxonomy of cryptic diversity exemplified by planktonic foraminifera. Syst Biol 65:925-940. doi: 10.1093/sysbio/syw031

Oken L (1815) Lehrbuch Der Naturgesehichte. Dritter Theil: Zoologie. Erste Abteilung, Fleischlose Thiere. August Schmid, Leipzig and Jena

AQ5

Pantos O, Bythell JC (2010) A novel reef coral symbiosis. Coral Reefs 29:761-770. doi: $10.1007 / \mathrm{s} 00338-010-0622-5$

Pantos O, Hoegh-Guldberg O (2011) Shared skeletal support in a coral-hydroid symbiosis. PLoS One 6:e20946. doi: 10.1371/journal.pone.0020946

Pearson RG (1981) Recovery and recolonization of coral reefs. Mar Ecol Prog Ser 4:105-122

Pica D, Bastari A, Vaga CF, Di Camillo CG, Montano S, Puce S (in press) Hydroid diversity of Eilat Bay with the description of a new Zanclea species. Mar Biol Res. doi: $10.1080 / 17451000.2016 .1236202$

Puce S, Cerrano C, Boyer M, Ferretti C, Bavestrello G (2002) Zanclea (Cnidaria: Hydrozoa) 
species from Bunaken Marine Park (Sulawesi Sea, Indonesia). J Mar Biol Assoc UK 82:943-954. doi: $10.1017 / \mathrm{S} 0025315402006434$

Puce S, Cerrano C, Di Camillo CG, Bavestrello G (2008a) Hydroidomedusae (Cnidaria: Hydrozoa) symbiotic radiation. J Mar Biol Assoc UK 88:1715-1721. doi: $10.1017 / \mathrm{S} 0025315408002233$

Puce S, Di Camillo CG, Bavestrello G (2008b) Hydroids symbiotic with octocorals from the Sulawesi Sea, Indonesia. J Mar Biol Assoc UK 88:1643-1654. doi: 10.1017/S0025315408001094

Raitsos DE, Pradhan Y, Brewin RJ, Stenchikov G, Hoteit I (2013) Remote sensing the phytoplankton seasonal succession of the Red Sea. PLoS One 8:e64909. doi: 10.1371/journal.pone.0064909

Randall JE (1994) Twenty-two new records of fishes from the Red Sea. Fauna Saudi Arabia $14: 259-275$

Renner SS (2016) A return to Linnaeus's focus on diagnosis, not description: the use of DNA characters in the formal naming of species. Syst Biol. doi: 10.1093/sysbio/syw032

Ronquist F, Teslenko M, van der Mark P et al (2012) MrBayes 3.2: efficient Bayesian phylogenetic inference and model choice across a large model space. Syst Biol 61:539-542. doi: 10.1093/sysbio/sys029

Rüppell E (1835) Description d'un nouveau genre de mollusques de la classe des Gastéropodes Pectinibranches. Trans Zool Soc Lond 1:259-260

Sammarco PW, Carleton JH (1981) Damselfish territoriality and coral community structure: reduced grazing, coral recruitment, and effects on coral spat. In: Proceedings of the 4th International Coral Reef Symposium, Manila, Philippines, May 1981, vol 2, pp 525-535

Sarkar IN, Thornton JW, Planet PJ, Figurski DH, Schierwater B, DeSalle R (2002) An automated phylogenetic key for classifying homeoboxes. Mol Phylogenet Evol 24:388-399. doi: 10.1016/S1055-7903(02)00259-2

Sarkar IN, Planet PJ, Desalle ROB (2008) CAOS software for use in character-based DNA barcoding. Mol Ecol Resour 8:1256-1259. doi: 10.1111/j.1755-0998.2008.02235.x

Scarpa F, Cossu P, Lai T, Sanna D, Curini-Galletti M, Casu M (2016) Meiofaunal cryptic species challenge species delimitation: the case of the Monocelis lineata (Platyhelminthes: Proseriata) species complex. Contrib Zool 85:123-145

Schindel DE, Miller SE (2010) Provisional nomenclature: the on-ramp to taxonomic names. In: Polaszek A (ed) Systema Naturae 250: the Linnaean Ark. CRC Press, Boca Raton, Florida, pp 109-116. doi: 10.1201/EBK1420095012-c10

Schuchert P (2014) High genetic diversity in the hydroid Plumularia setacea: a multitude of cryptic species or extensive population subdivision? Mol Phylogenet Evol 76:1-9. doi: 10.1016/j.ympev.2014.02.020 
Seveso D, Montano S, Pica D et al (2015) Pteroclava krempfi-octocoral symbiosis: new information from the Indian Ocean and the Red Sea. Mar Biodivers 46:483-487. doi: $10.1007 / \mathrm{s} 12526-015-0368-\mathrm{y}$

Shenkar N (2012) Ascidian (Chordata, Ascidiacea) diversity in the Red Sea. Mar Biodivers 42:459-469. doi: 10.1007/s12526-012-0124-5

Shipman C, Gosliner T (2015) Molecular and morphological systematics of Doto Oken, 1851 (Gastropoda: Heterobranchia), with descriptions of five new species and a new genus. Zootaxa 3973:57-101. doi: 10.11646/zootaxa.3973.1.2

Sofianos SS, Johns WE (2003) An oceanic general circulation model (OGCM) investigation of the Red Sea circulation: 2. Three-dimensional circulation in the Red Sea. J Geophys Res Oceans 108:3066. doi: 10.1029/2001JC001185

Stella JS, Pratchett MS, Hutchings PA, Jones GP (2011) Coral-associated invertebrates: diversity, ecological importance and vulnerability to disturbance. Oceanogr Mar Biol 49:43-104

Sukumaran J, Holder MT (2010) DendroPy: a Python library for phylogenetic computing. Bioinformatics 26:1569-1571. doi: 10.1093/bioinformatics/btq228

Talavera G, Castresana J (2007) Improvement of phylogenies after removing divergent and ambiguously aligned blocks from protein sequence alignments. Syst Biol 56:564 577. doi: $10.1080 / 10635150701472164$

AQ6

Tamura K, Stecher G, Peterson D, Filipski A, Kumar S (2013) MEGA6: molecular evolutionary genetics analysis version 6.0. Mol Biol Evol 30:2725-2729. doi: 10.1093/molbev/mst197

Terraneo TI, Berumen ML, Arrigoni R et al (2014) Pachyseris inattesa sp. n. (Cnidaria, Anthozoa, Scleractinia): a new reef coral species from the Red Sea and its phylogenetic relationships. ZooKeys 433:1-30. doi: 10.3897/zookeys.433.8036

Tornabene L, Ahmadia GN, Williams JT (2013) Four new species of dwarfgobies (Teleostei: Gobiidae: Eviota) from the Austral, Gambier, Marquesas and Society Archipelagos, French Polynesia. Syst Biodivers 11:363-380. doi: 10.1080/14772000.2013.819822

van der Meij SE, Fransen CH, Pasman LR, Hoeksema BW (2015) Phylogenetic ecology of gall crabs (Cryptochiridae) as associates of mushroom corals (Fungiidae). Ecol Evol 5:5770-5780. doi: $10.1002 /$ ece 3.1808

Wallace CC (1983) A comparison of two consecutive spring-summer juvenile coral recruitment seasons on a reef front. Bull Mar Sci 33:783

Wallace CC (1985) Reproduction, recruitment and fragmentation in nine sympatric species of the coral genus Acropora. Mar Biol 88:217-233. doi: 10.1007/BF00392585

Wallace CC, Bull GD (1982) Patterns of juvenile coral recruitment on a reef front during a spring-summer spawning period. In: Proceedings of the 4th International Coral Reef Symposium, Manila, Philippines, May 1981, vol 2, pp 345-350 
Zielske S, Haase M (2015) Molecular phylogeny and a modified approach of character-based barcoding refining the taxonomy of New Caledonian freshwater gastropods (Caenogastropoda, Truncatelloidea, Tateidae). Mol Phylogenet Evol 89:171-181. doi: 10.1016/j.ympev.2015.04.020

Zietara MS, Arndt A, Geets A, Hellemans B, Volckaert FA (2000) The nuclear rDNA region of Gyrodactylus arcuatus and G. branchicus (Monogenea: Gyrodactylidae). J Parasitol 86:1368-1373. doi: 10.1645/0022-3395(2000)086[1368:TNRROG]2.0.CO;2

Zou S, Li Q, Kong L, Yu H, Zheng X (2011) Comparing the usefulness of distance, monophyly and character-based DNA barcoding methods in species identification: a case study of Neogastropoda. PLoS One 6:e26619. doi: 10.1371/journal.pone.0026619

Zwickl DJ (2006) GARLI: genetic algorithm for rapid likelihood inference. Home page at: http://www.bio.utexas.edu/faculty/antisense/garli/garli.html . Accessed 31 July 2016 